\title{
OPTIMASI PERANCANGAN AGITATOR PADA ALAT PENCAMPUR LARUTAN NUTRISI HIDROPONIK DENGAN PERTIMBANGAN FREKUENSI PRIBADI
}

\section{DESIGN OPTIMIZATION OF AGITATOR FOR HYDROPONIC NUTRIENT MIXER WITH NATURAL FREQUENCY CONSIDERATION}

\author{
Aidil Haryanto, Seri Intan Kuala \\ Pusat Penelitian Teknologi Tepat Guna-LIPI \\ Jl. KS Tubun No.5 Subang Jawa Barat, (0260)411478 \\ e-mail : aharyant03@gmail.com
}

\begin{abstract}
ABSTRAK
Agitator merupakan komponen yang penting dari sistem pencampuran larutan nutrisi tanaman hidroponik. Rancangan agitator yang optimal dapat meningkatkan kinerja proses pencampuran sehingga larutan nutrisi hidroponik yang dihasilkan dapat bercampur dengan merata. Agitator yang telah ada dioptimasi dengan rancangan sesuai metode mechanical design of mixing equipment. Optimasi perancangan juga mempertimbangkan frekuensi pribadi yaitu dengan menganalisis frekuensi getaran dan kecepatan putar kritis menggunakan analisis elemen hingga. Tipe sudu agitator yaitu pitch blade turbine (PBT) dengan perbedaan antara agitator sebelum dan sesudah optimasi terdapat pada jumlah sudu agitator, diameter sudu agitator, dan diameter poros. Hasil analisis frekuensi pribadi menghasilkan diagram Campbell yang dapat mengetahui hubungan frekuensi getaran dan kecepatan putar. Kecepatan kritis berdasarkan analisis frekuensi getaran tidak berada dikisaran kecepatan putar kerja agitator sehingga desain dianggap aman dan tidak memiliki resiko kegagalan.
\end{abstract}

Kata Kunci : agitator, elemen hingga, frekuensi pribadi, hidroponik

\begin{abstract}
The agitator is an important component of a system for mixing hydroponic nutrient solutions. The optimal agitator design can improve the performance of the mixing process so that the resulting hydroponic nutrient solution can be mixed evenly. The existing agitator is optimized with a design that is suitable for mechanical design of mixing equipment methods. Design optimization also considers natural frequency by analyzing vibration frequency and critical speeds using finite element analysis. The type of agitator blade is pitch blade turbine (PBT) with the difference between agitators before and after optimization in the number of agitator blades, agitator blade diameter, and shaft diameter. The results of natural frequency analysis produce a Campbell diagram that can determine the relationship between vibration frequency and rotational speed. Critical speed based on vibration frequency analysis is not in the range of the rotating speed of the agitator.So the design is considered safe and has no risk of failure.
\end{abstract}

Keywords : agitator, finite element, natural frequency, hydroponic.

\section{PENDAHULUAN}

ecara komprehensif ketahanan pangan merupakan suatu sistem yang terdiri dari tiga subsistem yaitu ketersediaan pangan dalam jumlah dan jenis yang mencukupi, distribusi pangan yang lancar dan merata, konsumsi pangan setiap individu yang memenuhi kecukupan gizi seimbang yang berdampak pada status gizi masyarakat (Suharyanto, 2011). 
Salah satu upaya penyediaan pangan adalah melalui produksi makanan organik, bahwa produk organik telah mendominasi pasar di berbagai negara-negara yang telah mengalami perkembangan ekonomi yang dapat memberikan manfaat bagi produsen maupun konsumen (Hubeis et al., 2013).

Salah satu metode yang dapat diterapkan untuk mendapatkan produk pangan organik, produk tanaman dengan kualitas dan kuantitas yang tinggi serta kontinyu yaitu menggunakan sistem tanam hidroponik (Rosliani et al., 2005). Kualitas dan kuantitas tanaman hidroponik sangat bergantung pada konsentrasi larutan nutrisi (Trejo-Téllez and Gómez-Merino, 2012). Konsentrasi merupakan perbandingan jumlah zat terlarut dalam tiap satuan pelarut, sedangkan larutan adalah campuran homogen dari dua jenis zat atau lebih. Dalam hidroponik konsentrasi larutan dapat diindikasikan dengan nilai TDS (Total Disolved Solid) dengan satuan ppm (part permilion) dan nilainya berbeda untuk setiap tanaman (Kuala, Siregar and Susanti, 2016).

Konsentrasi larutan hidroponik sangat tergantung pada proses pencampuran larutan nutrisi ke dalam air baku yang nantinya akan disalurkan keseluruh sistem. Pencampuran bermanfaat untuk mendapatkan karakteristik bahan yang sesuai (Wirakartakusumah, 1992). Dalam hidroponik pencampuran bertujuan untuk mendapatkan kekonsentrasi larutan nutrisi yang homogen.

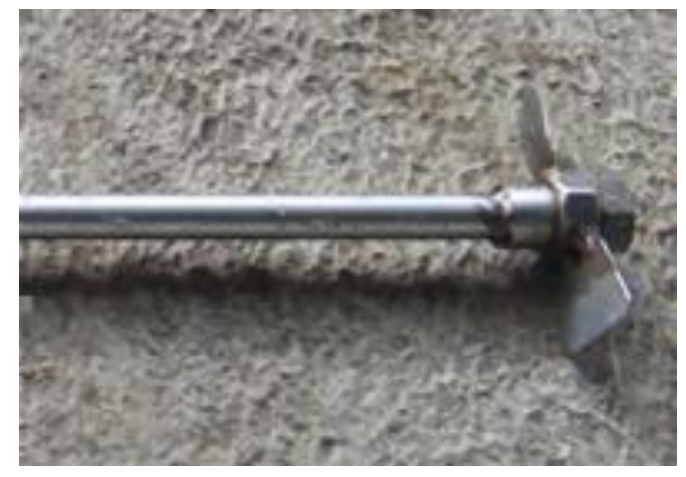

Gambar 1. Agitator yang Telah Dibuat

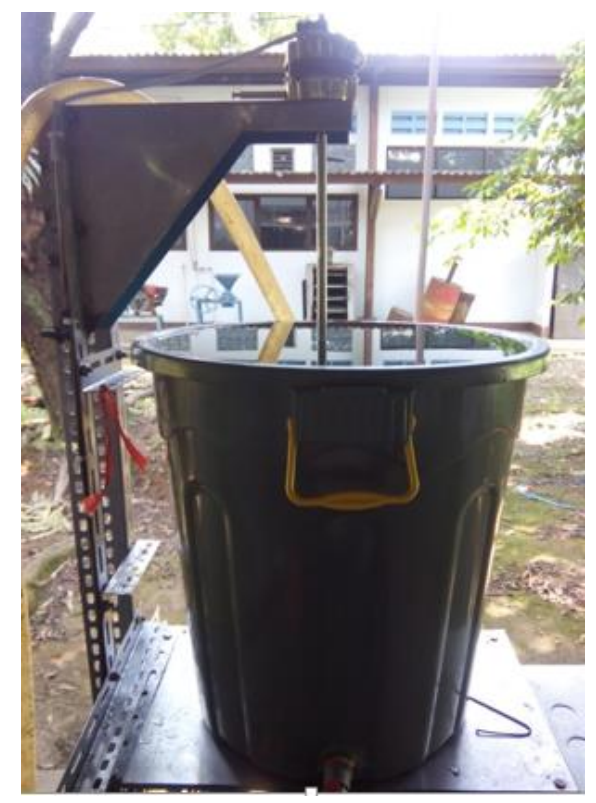

Gambar 2. Alat Pencampur Larutan Nutrisi Hidroponik 
Pada proses pencampuran, alat yang digunakan terdiri dari komponen utama berupa bak penampung kapasitas 60 liter dengan material plastik, poros agitator diameter $10 \mathrm{~mm}$, sudu pencampur tipe pitch blade turbine (PBT) dengan dua sudu terletak di ujung poros berdiameter $68 \mathrm{~mm}$, serta motor penggerak 45 watt. Material yang digunakan untuk poros dan sudu pencampur SS 304 seperti pada Gambar 1 dan Gambar 2. Pada alat tersebut, agitator dibuat tanpa melalui proses perancangan dan pertimbangan getaran yang terjadi akibat poros yang berputar. Agitator tidak dilakukan perancangan poros dan sudu pencampur secara detail, hal ini menyebabkan tidak optimalnya kerja alat pencampur dan memungkinkan terjadinya desain yang berlebihan baik itu dari dimensi poros maupun sudu pencampur.

Oleh sebab itu, penelitian ini bertujuan untuk mendapatkan perancangan poros dan sudu pencampur yang optimal dengan melakukan perancangan ulang dan optimasi perancangan dengan pertimbangan frekuensi pribadi. Secara umum konfigurasi standar agitator seperti Gambar 3. Frekuensi pribadi merupakan karakterisitik dinamik dari sistem poros rotor. Frekuensi pribadi perlu diperhitungan akibat dari kecepatan putar poros agitator yang dapat menyebabkan getaran yang tidak teredam (Paul, Atiemo-obeng and Kresta, 2004). Getaran tersebut secara mendadak dapat menyebabkan kegagalan pada poros agitator. Pada kondisi tertentu jika poros mengalami kegagalan akan membahayakan operator. Kondisi operasi yang harus dihindari yaitu pada atau dekat frekuensi pribadi. Analisis frekuensi pribadi menggunakan pendekatan analisis elemen hingga yang dapat meningkatkan keakurasian hasil analisis.

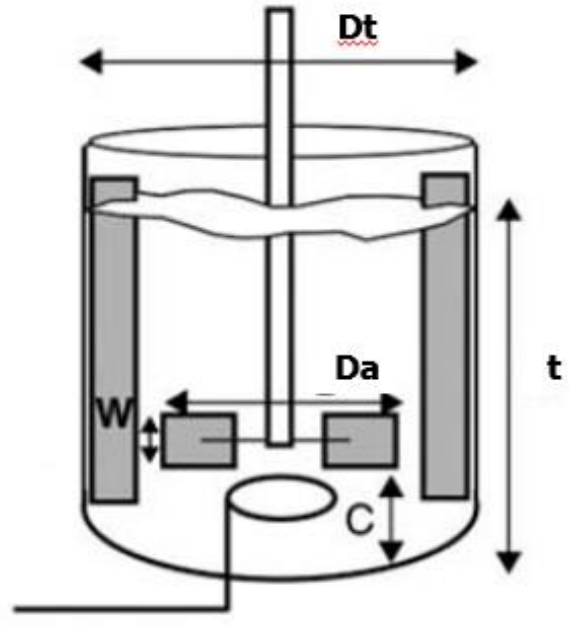

Gambar 3. Konfigurasi Standar Agitator. (Parvizi et al., 2016)

\section{METODE PENELITIAN}

Metode penelitian menggunakan prinsip rancangan dari mechanical design of mixing equipment (Paul, Atiemo-obeng and Kresta, 2004).

\section{Alat dan Bahan}

Pada analisis frekuensi pribadi, perangkat lunak yang digunakan yaitu perangkat lunak CAD (Computer Aided Design) dan perangkat lunak CAE (Computer Aided Engineering). CAD digunakan untuk menggambar rancangan agitator sedangkan $C A E$ digunakan untuk menganalisis frekuensi pribadi rancangan agitator dengan metode elemen hingga. Metode elemen hingga pada perangkat lunak $C A E$ dalam menyelesaikan permasalahan getaran dan frekuensi pribadi pada sistem poros rotor yaitu pseudo-modal method yang merupakan metode penyelesaian sangat cepat dan efisien (Paulo, 2011; Haryanto, 2018). 


\section{Representasi Elemen Hingga}

Analisis frekuensi pribadi agitator pada pencampuran larutan nutrisi hidroponik menggunakan sistem poros rotor (rotor dynamic) dengan menggunakan persamaan energi kinetik (kinetic energy) dan energi regangan (strain energy) dari setiap elemen rotor serta pengaruh gaya luar yang terjadi.

Komponen sistem poros rotor yang menjadi pertimbangannya yaitu sudu yang diasumsikan sebuah piringan (disk) dalam keadaan kaku, poros (shaft), dan bantalan (bearing) yang diasumsikan berupa tumpuan jepit (Tiwari, 2010). Rotor diasumsikan tanpa beban (free motion). Analisis dilakukan menggunakan metode elemen hingga untuk mendapatkan derajat kebebasan yang lebih banyak sehingga meningkatkan keakurasian. Metode elemen hingga biasanya digunakan untuk masalah getaran dari struktur dan mekanikal yang sangat kompleks (Rao, 2011).

Secara umum persamaan gerak untuk menghitung frekuensi pribadi :

$$
[M] \ddot{x}+[C](\Omega) \dot{x}+[K] x=0
$$

Dimana $[\mathrm{M}]=$ jumlah matriks massa semua komponen, $[\mathrm{C}]=$ matriks efek giroskopik atau matriks redaman semua komponen, dan $[\mathrm{K}]$ = matriks kekakuan semua komponen

Persamaan pseudo-modal method di bawah ini diselesaikan untuk mendapatkan eigen value dan eigen vector (frekuensi pribadi dan modus getar) dari matriks pertama persamaan tersebut (Lallane and Ferraris, 1998).

$$
\left[\begin{array}{cc}
0 & I \\
m^{-1} k & m^{-1} c
\end{array}\right]\left[\begin{array}{c}
r P \\
P
\end{array}\right]=\frac{1}{2}\left[\begin{array}{c}
r P \\
P
\end{array}\right]
$$

Dimana $\mathrm{m}=$ matriks massa, $\mathrm{k}=$ matriks kekakuan, $\mathrm{c}=$ matriks efek giroskopik

1) Persamaan gerak disk

Disk rotor dengan dua nodal mempunyai empat derajat kebebasan dengan persamaan elemen hingga :

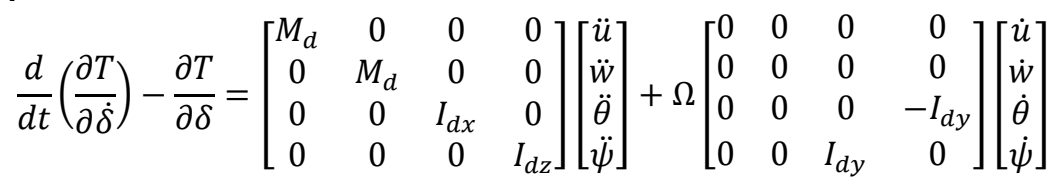

Dimana $\mathrm{Md}=$ massa disk $(\mathrm{kg})$, dan I = momen inersia massa disk $\left(\mathrm{kgm}^{2}\right)$

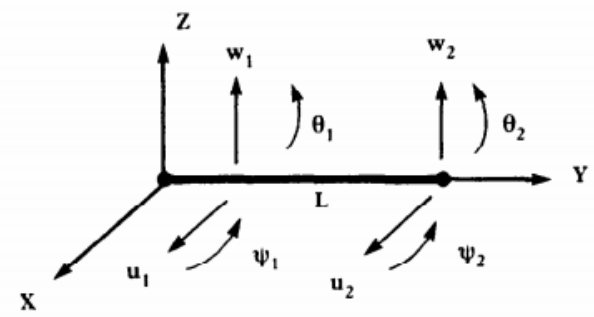

Gambar 4. Modus Getar.(Lallane and Ferraris, 1998)

2) Persamaan gerak poros

Poros merupakan elemen batang yang dipengaruhi oleh modus getar penyebab terjadinya bending. Pada kasus ini, nodal dipengaruhi oleh perpindahan translasi dan rotasi. Persamaan gerak poros : (Rao, 2011) 


$$
[K]=\frac{E I}{L^{3}}\left[\begin{array}{cccc}
12 & 6 L & -12 & 6 L \\
6 L & 4 L^{2} & -6 L & 2 L^{2} \\
-12 & -6 L & 12 & -6 L \\
6 L & 2 L^{2} & -6 L & 4 L^{2}
\end{array}\right]
$$

$$
\begin{aligned}
\operatorname{Dengan}\{x\}=\left\{\begin{array}{l}
u_{1} \\
\theta_{1} \\
u_{2} \\
\theta_{2}
\end{array}\right\} \text {, dan } L=\text { panjang poros }(\mathrm{m}) \\
{[M]=\frac{\rho A L}{420}\left[\begin{array}{cccc}
156 & 22 L & 54 & -13 L \\
22 L & 4 L^{2} & 13 L & -3 L^{2} \\
54 & 13 L & 156 & -22 L \\
-13 L & -3 L^{2} & -22 L & 4 L^{2}
\end{array}\right] }
\end{aligned}
$$$$
\operatorname{Dengan}\{\ddot{x}\}=\left\{\begin{array}{l}
\ddot{u}_{1} \\
\ddot{\theta}_{1} \\
\ddot{u}_{2} \\
\ddot{\theta}_{2}
\end{array}\right\}, \rho=\text { massa jenis }\left(\mathrm{kg} / \mathrm{m}^{3}\right), \mathrm{A}=\text { luas penampang }\left(\mathrm{m}^{2}\right)
$$

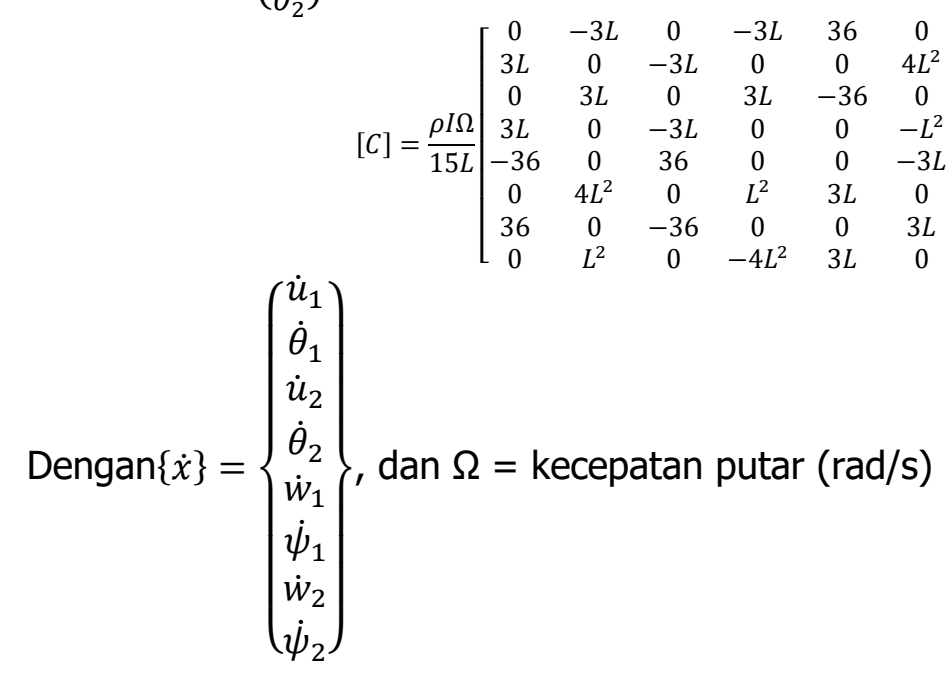

\section{HASIL DAN PEMBAHASAN}

\section{Perancangan}

\section{1) Data awal}

Dalam perancangan agitator telah ditentukan kondisi batas beberapa parameter seperti pada Tabel 1.

Tabel 1. Data Awal

\begin{tabular}{cll}
\hline No & \multicolumn{1}{c}{ Parameter } & \multicolumn{1}{c}{ Nilai } \\
\hline 1 & Material agitator & SS 304 \\
2 & Temperatur kerja max & $33{ }^{\circ} \mathrm{C}$ \\
3 & Kecepatan putar $(\mathrm{N})$ & $150 \mathrm{RPM}$ \\
4 & Volume kerja $\left(\mathrm{V}_{\text {air }}\right)$ & $43 \mathrm{Liter}$ \\
5 & TDS larutan* & $6351,8 \mathrm{ppm}$ \\
6 & Massa jenis larutan $(\rho) *$ & $953 \mathrm{~kg} / \mathrm{m}^{3}$ \\
7 & Tinggi bak $(\mathrm{t})$ & $500 \mathrm{~mm}$ \\
8 & Radius atas bak $\left(\mathrm{r}_{\mathrm{a}}\right)$ & $235 \mathrm{~mm}$ \\
9 & Radius bawah bak $\left(\mathrm{r}_{\mathrm{b}}\right)$ & $185 \mathrm{~mm}$ \\
\hline \multicolumn{2}{c}{ *Berdasarkan pengujian }
\end{tabular}

\section{Aidil Haryanto, Seri Intan Kuala}


2) Pemilihan posisi agitator dan sudu agitator

Posisi agitator sedikit kepinggir atau tidak tepat di tengah untuk menghindari terjadinya pusaran yang diakibatkan karena bak penampung tidak menggunakan baffle. Pemilihan sudu tipe PBTdengan 4 sudu kemiringan $45^{\circ}$ dipilih berdasarkan penilaian syarat dan tujuan perancangan dengan berbagai altenatif sudu agitator antara lain; bekerja pada viskositas rendah (12,2 x $10^{-4}$ Pa.s), proses manufaktur dan perkaitan yang mudah, dan untuk mendapatkan aliran aksial dan radial secara bersamaan untuk mengoptimalkan pencampuran.

Jumlah sudu pada turbin impeller bervariasi dari 2 sampai 12 buah. Dua sudu berdasarkan mekanikal akan menyebabkan ketidakstabilan saat berputar dan akan menyebabkan terjadinya getaran mekanik. Secara umum, sudu aliran aksial mempunyai tiga atau empat sudu (Paul, Atiemo-obeng and Kresta, 2004). Sudut kemiringan sudu terhadap arah horizontal antara $10^{\circ}$ sampai $90^{\circ}$, dan secara umum sudut sudu sebesar $45^{\circ}$.

\section{3) Perancangan geometri}

Geometri agitator dapat ditentukan dengan menggunakan Tabel 2 yang merupakan rasio geometri untuk sudu tipe PBT dengan 4 sudu kemiringan 450. Bak diasumsikan berbentuk silinder dengan diameter yang sama. Pada perancangan ini, diameter bak merupakan diameter rata-rata antara diameter bak atas dengan bawah. Berdasarkan hasil perhitungan rasio geometri menghasilkan tinggi larutan (H) 309 mm, diameter bak 420 mm, diameter sudu 140 $\mathrm{mm}$, clearance atau selisih antara $D_{a}$ dengan $D_{t} 140 \mathrm{~mm}$, dan lebar sudu $17,5 \mathrm{~mm}$.

Tabel 2. Rasio Geometri. (Paul, Atiemo-obeng and Kresta, 2004)

\begin{tabular}{l}
$\frac{D_{a}}{D_{t}}=\frac{1}{3} \quad \frac{W}{D_{a}}=\frac{1}{8} \quad \frac{D_{a}}{C}=1$ \\
\hline$D_{a}=$ Diameter sudu agitator $(\mathrm{mm})$ \\
$D_{t}=$ Diameter bak $(\mathrm{mm})$ \\
$W=$ Lebar sudu agitator $(\mathrm{mm})$ \\
$C=$ Clearance $(\mathrm{mm})$
\end{tabular}

Pengembangan kriteria (Dickey, 2012) seperti pada Tabel 3, berdasarkan viskositas larutan dan rasio antara tinggi larutan dan diameter bak $\left(\mathrm{H} / \mathrm{D}_{\mathrm{t}}\right)$ maka jumlah/ tingkat sudu yang digunakan satu tingkat.

Tabel 3. Jumlah/Tingkat Sudu

\begin{tabular}{|c|c|c|c|c|}
\hline \multirow[b]{2}{*}{$\begin{array}{l}\text { Viskositas } \\
(\mathrm{cP}(\text { Pa.s)) }\end{array}$} & \multirow{2}{*}{$\begin{array}{l}\text { Level } \\
\text { maks } \\
\left(\mathrm{H} / \mathrm{D}_{\mathrm{t}}\right)\end{array}$} & \multirow[b]{2}{*}{$\begin{array}{l}\text { Jumlah } \\
\text { sudu }\end{array}$} & \multicolumn{2}{|c|}{ Clearance sudu } \\
\hline & & & $\begin{array}{c}\text { Sudu } \\
\text { bawah }\end{array}$ & $\begin{array}{l}\text { Sudu } \\
\text { atas }\end{array}$ \\
\hline$<25000(<25)$ & 1,4 & 1 & $\mathrm{H} / 3$ & - \\
\hline$<25000(<25)$ & 2,1 & 2 & $D_{t} / 3$ & $(2 / 3) \mathrm{H}$ \\
\hline$>25000(>25)$ & 0,8 & 1 & $H / 3$ & - \\
\hline$>25000(>25)$ & 1,6 & 2 & $D_{t} / 3$ & $(2 / 3) \mathrm{H}$ \\
\hline
\end{tabular}

4) Perhitungan daya yang bekerja

Konsumsi daya (power) dari sebuah agitator dapat dihitung dengan persamaan :(Paul, Atiemo-obeng and Kresta, 2004; Desai, Gajjal and Kulloli, 2016)

$$
P=\frac{N_{P} \rho \Omega^{3} D_{a}{ }^{5}}{g}
$$

Dimana $\mathrm{P}=$ daya (wattt), $\mathrm{N}_{\mathrm{P}}=$ bilangan daya (power number), $\Omega=$ kecepatan putar $(\mathrm{rad} / \mathrm{s}), \mathrm{g}=$ percepatan gravitasi $\left(\mathrm{m} / \mathrm{s}^{2}\right)$ 
Bilangan reynolds (Reynolds number) dihitung menggunakan persamaan di bawah untuk menentukan bilangan daya:

$$
R e=\frac{\rho \Omega D_{a}{ }^{2}}{\mu}
$$

Dimana $\mathrm{Re}=$ bilangan reynolds, $\mu=$ viskositas (Pa.s).

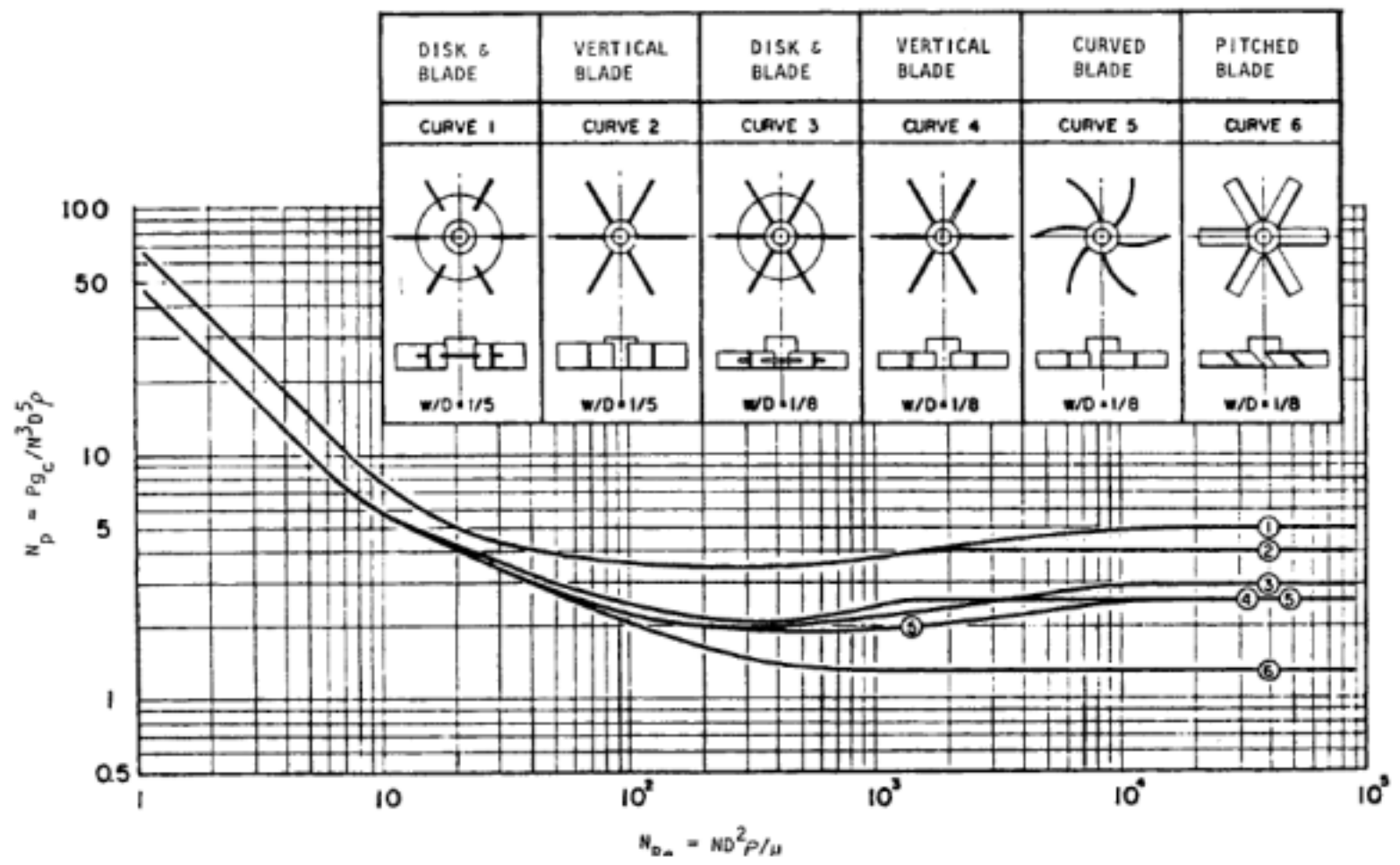

Gambar 5. Grafik Hubungan Bilangan Reynolds dan Bilangan Daya. (Paul, Atiemo-obeng and Kresta, 2004)

Untuk menentukan bilangan daya pada sudu tipe PBT dengan memplot pada grafik hubungan bilangan reynolds dengan bilangan daya seperti Gambar 5. Hasil perhitungan untuk bilangan reynolds $241,3 \times 10^{3}$, bilangan daya 1,5dan daya yang dihasilkan 30,3 watt.

5) Perancangan poros agitator

Menurut (Wilson, 1997) torsi pada kondisi operasi suatu poros dapat digunakan untuk menghitung daya kerja. Hubungan torsi dan daya akan dipertimbangkan ketika merancang suatu komponen pentransmisi daya. Hubungan daya, torsi, dan kecepatan putar poros agitator pada proses pencampuran larutan nutrisi hidroponik menggunakan persamaan :

$$
P=T . \Omega
$$

Dimana $\mathrm{T}=$ torsi $(\mathrm{Nm})$

Kesetimbangan gaya dan momen dapat menggunakan persamaan $\Sigma F=0$ dan $\Sigma M=0, F$ merupakan gaya $(\mathrm{N})$ dan $\mathrm{M}$ adalah momen $(\mathrm{Nm})$ untuk mengidentifikasi semua gaya dan momen yang bekerja pada agitator 
Untuk menghitung diameter poros minimum yang dapat digunakan pada agitator pencampur larutan nutrisi hidroponik dapat menggunakan persamaan : (Paul, Atiemo-obeng and Kresta, 2004)

$$
d=\left(\frac{16 \sqrt{T^{2}+M^{2}}}{\pi \tau}\right)^{1 / 3}
$$

Dimana $\mathrm{d}=$ diameter poros minimum $(\mathrm{mm}), \tau=$ tegangan geser $(\mathrm{MPa})$

Panjang poros diasumsikan sama dengan tinggi bak sebesar $500 \mathrm{~mm}$. Diameter poros minimum yang dapat digunakan untuk menahan kombinasi momen lentur dan torsi menggunakan material SS 304 akibat pengaruh tegangan geser sebesar $8 \mathrm{~mm}$. data hasil perhitungan dapat dilihat pada Tabel 4.

Tabel 4. Data Hasil Perhitungan

\begin{tabular}{lcl}
\hline Parameter & Simbol & \multicolumn{1}{c}{ Nilai } \\
\hline Torsi & $\mathrm{T}$ & $1,9 \times 10^{3} \mathrm{Nmm}$ \\
Gaya persudu & $\mathrm{F}$ & $13,8 \mathrm{~N}$ \\
Momen & $\mathrm{M}$ & $6,9 \times 10^{3} \mathrm{Nmm}$ \\
Yield strength SS 304 & $\sigma_{\mathrm{y}}$ & $206,8 \mathrm{MPa}$ \\
Safety factor & $\mathrm{SF}$ & 1,5 \\
Allowable stress & $\sigma_{\mathrm{t}}$ & $137,9 \mathrm{MPa}$ \\
Allowable shear stress & $\mathrm{T}$ & $68,9 \mathrm{Mpa}$ \\
Diameter poros minimum & $\mathrm{D}$ & $8 \mathrm{~mm}$ \\
\hline
\end{tabular}

6) Perhitungan tebal sudu agitator

Metode energi (energy methods) digunakan untuk menghitung dan menganalisis tebal sudu agitator. Metode ini merupakan metode alternatif pendekatan langsung berdasarkan defleksi. Dengan mengasumsikan tebal sehingga mendapatkan defleksi optimal yang dianggap masih aman (Haryanto, 2018). Tebal sudu agitator dapat dihitung dengan persamaan : (Barber, 2000)

$$
\begin{gathered}
U=\frac{1}{2} F u \\
U=\frac{1}{2} \int_{0}^{L} \frac{M^{2} d z}{E I}
\end{gathered}
$$

Dimana $\mathrm{U}=$ strain energy, $\mathrm{u}=$ defleksi $(\mathrm{mm}), \mathrm{E}=$ modulus elastisitas $(\mathrm{GPa})$, dan $\mathrm{I}=$ momen inersia $\left(\mathrm{mm}^{4}\right)$

Kemampuan sudu agitator tipe PBT untuk menahan beban yang dipengaruhi larutan nutrisi hidoponik ketika dalam kondisi operasi yaitu berasal dari ketebalan. Sudu yang memiliki ketebalan yang kurang akan menyebabkan sudu melengkung dan juga harus menghindari over design. Tebal sudu agitator yang optimal berdasarkan persamaan di atas yaitu $1 \mathrm{~mm}$

\section{Analisis Elemen Hingga}

Model sistem poros rotor seperti Gambar 6. Bantalan di salah satu ujung poros diasumsikan berupa tumpuan jepit. Pada ujung poros lainnya dalam kondisi bebas dengan disk diposisikan pada ujung tersebut. 


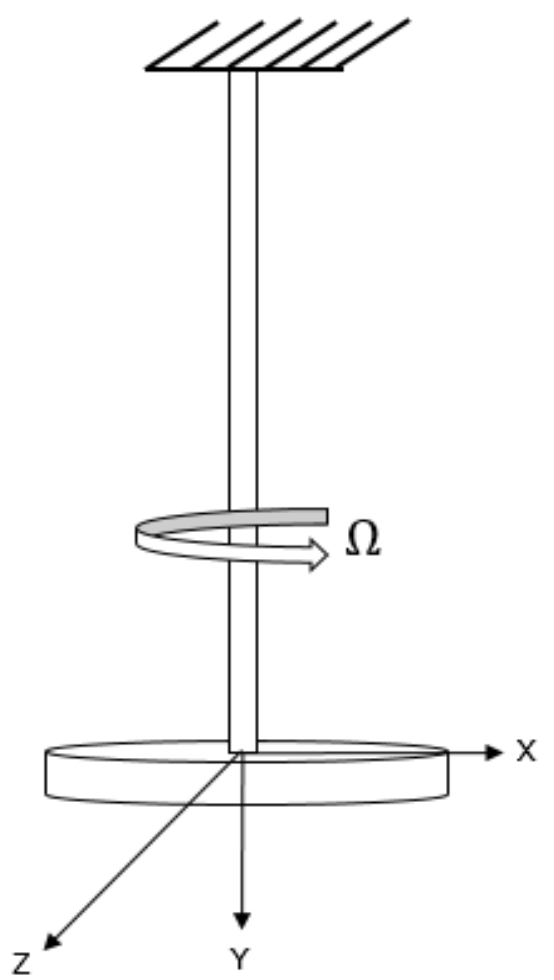

Gambar 6. Model Sistem Poros Rotor

Sifat mekanik rotor yang diperlukan untuk analisis elemen hingga seperti pada Tabel 5. Diagram yang merepresentasikan hasil pemodelan antara frekuensi getaran dengan kecepatan putar seperti pada Gambar 7 merupakan diagram campbell.

Tabel 5. Sifat Mekanik Rotor untuk Analisis Elemen Hingga

\begin{tabular}{lll}
\hline \multicolumn{3}{c}{ Disk Kaku } \\
\hline 1 & Massa & $0,037 \mathrm{~kg}$ \\
2 & Radius dalam & $0,004 \mathrm{~m}$ \\
3 & Radius luar & $0,070 \mathrm{~m}$ \\
4 & Ketebalan & $0,0003 \mathrm{~m}$ \\
5 & Momen inersia massa melintang & $4,5396 \mathrm{e}-05 \mathrm{kgm}^{2}$ \\
6 & Momen inersia massa polar & $9,07915 \mathrm{e}-03 \mathrm{kgm}{ }^{2}$ \\
\hline \multicolumn{2}{c}{ Poros } \\
\hline 1 & Diameter & $0,008 \mathrm{~m}$ \\
2 & Panjang & $0,5 \mathrm{~m}$ \\
3 & Momen inersia penampang & $2,10311 \mathrm{e}-10 \mathrm{~m}^{4}$ \\
4 & Modulus elastisitas & $1,9 \mathrm{e}+11 \mathrm{~N} / \mathrm{m}^{2}$ \\
5 & Massa jenis (SS 304) & $8000 \mathrm{~kg} / \mathrm{m}^{3}$ \\
\hline
\end{tabular}




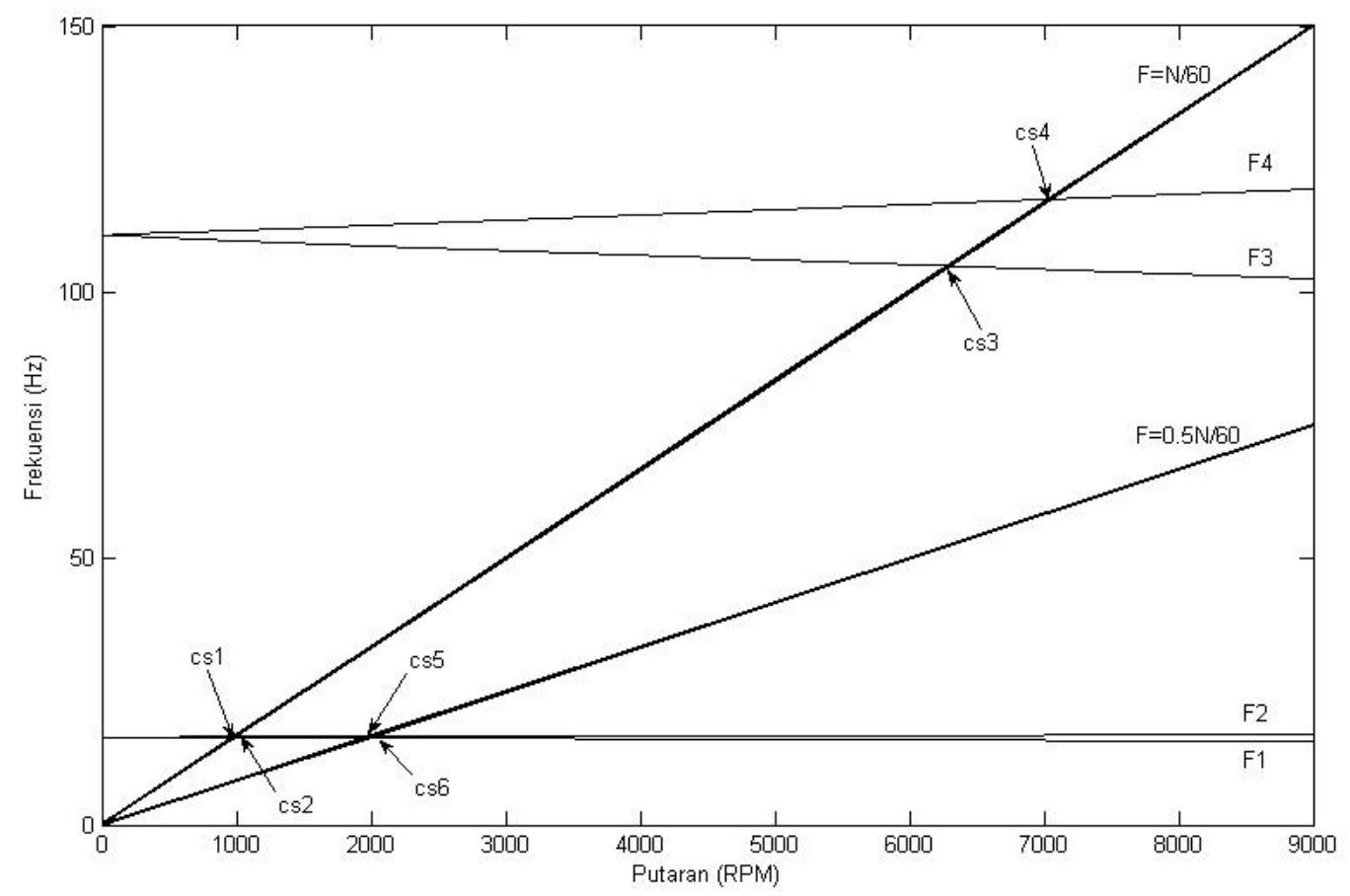

Gambar 7. Diagram Campbell dan Kecepatan Putar Kritis

Sistem berputar pada agitator akan memiliki resiko kegagalan ketika beroperasi pada kecepatan putar tertentu yang disebut kecepatan putar kritis atau critical speed (Agostini and Souza, 2010). Pada Gambar 7, kecepatan putar kritis (cs) terjadi pada perpotongan antara frekuensi rotor sama dengan frekuensi putaran (N/60) dan frekuensi rotor sama dengan setengah dari frekuensi putaran (0,5N/60). Terdapat enam kecepatan putar kritis yang harus dihindari berdasarkan perancangan cs1, cs2, cs3, cs4, cs5, dan cs6. Kecepatan putar kritis dapat dilihat pada Tabel 6.

Tabel 6. Kecepatan Putar Kritis Pada Modus Getar

\begin{tabular}{cccc}
\hline & $\begin{array}{c}\text { Kecepatan putar kritis } \\
(\text { RPM) }\end{array}$ & Modus putar & Modus getar \\
\hline cs1 & 985,22 & Forward & Pertama \\
cs2 & 993,92 & Backward & Pertama \\
cs3 & 6295,03 & Backward & Kedua \\
cs4 & 7046,37 & Forward & Kedua \\
cs5 & 1961,94 & Forward & Pertama \\
cs6 & 1996,53 & Backward & Pertama \\
\hline
\end{tabular}

Agitator pada kondisi diam $(\Omega=0)$, perhitungan frekuensi dan modus getar ditentukan oleh momen lentur dan putaran. Pada saat berputar kedua frekuensi dan modus getar yang dihasilkan seperti Gambar 7 masing-masing terpisah menjadi dua modus getar dengan modus putar menjadi forward dan backward. Modus getar pertama yaitu F1 dan F2, modus getar kedua F3 dan F4. Modus putar mengalami forward jika putaran berbanding lurus dengan frekuensi (F2 dan F4), sebaliknya untuk modus putar backward (F1 dan F3). 


\section{Perbandingan Parameter Agitator Sebelum dan Sesudah Optimasi}

Perbedaan antara agitator sebelum dengan setelah optimasi dan dengan pertimbangan frekuensi pribadi dapat dilihat pada Tabel 7.

Tabel 7. Parameter Agitator Sebelum dan Sesudah Optimasi

\begin{tabular}{clcc}
\hline No & Parameter & $\begin{array}{c}\text { Agitator } \\
\text { sebelumnya }\end{array}$ & $\begin{array}{c}\text { Agitator hasil } \\
\text { optimasi }\end{array}$ \\
\hline 1 & Tipe agitator & PBT & PBT \\
2 & Jumlah tingkatan & 1 tingkat & 1 tingkat \\
3 & Jumlah sudu & $2 \mathrm{sudu}$ & 4 sudu \\
4 & Diameter poros & $10 \mathrm{~mm}$ & $8 \mathrm{~mm}$ \\
5 & Daya & $60 \mathrm{watt}$ & $30 \mathrm{watt}$ \\
6 & Diameter sudu & $68 \mathrm{~mm}$ & $140 \mathrm{~mm}$ \\
7 & Tebal sudu & $1 \mathrm{~mm}$ & $1 \mathrm{~mm}$ \\
8 & Clearance & - & $140 \mathrm{~mm}$ \\
9 & Lebar sudu & - & $17,5 \mathrm{~mm}$ \\
\hline
\end{tabular}

\section{KESIMPULAN}

Agitator yang telah dibuat sebelumnya tanpa menggunakan metode perancangan untuk proses pencampuran. Agitator tersebut tidak mempertimbangkan clearance dan diameter sudu berdasarkan rasio geometri untuk PBT yang memungkinkan tidak terjadi pengadukan dan pencampuran yang sempurna disekitar dinding bak. Optimasi agitator yang didapatkan dari hasil perancangan ulang yaitu diameter poros dari $10 \mathrm{~mm}$ menjadi $8 \mathrm{~mm}$, daya yang dibutuhkan dari 60 watt menjadi 30 watt. Agitator beroperasi dengan kecepatan putar 150 RPM berdasarkan diagram campbell tidak memiliki resiko kegagalan yang disebabkan oleh frekuensi getaran dengan kecepatan putar kritis tidak berada dikisaran kecepatan putar operasi. Hasil analisis elemen hingga yang telah dilakukan dapat dibandingkan dengan analisis elemen hingga menggunakan menggunakan metode Rayleigh-Ritz untuk memvalidasi ketepatan simulasi.

\section{UCAPAN TERIMA KASIH}

Pusat Penelitian Teknologi Tepat Guna - Lembaga Ilmu Pengetahuan Indonesia

\section{DAFTAR PUSTAKA}

Agostini, C. E. and Souza, C. E. 2010. Complex Modal Analysis of A Vertical Rotor by Finite Elements Method. in the 9th Brazilian Conference on Dynamics Control and their Applications. Serra Negra, pp. 449-457.

Barber, J. R. 2000. Intermediate Mechanics of Materials. Second. Edited by G. M. L. Gladwell. Michigan: Springer. Available at: www.springer.com/series/6557.

Desai, S. R., Gajjal, S. Y. and Kulloli. 2016. Redesign and Structural Analysis of Agitator Shaft for Reactor Pressure Vessel. pp. 268-273. Available at: http://inpressco.com/category/ijcet.

Dickey, D. S. 2012. Handbook of Chemical Engineering Calculations. 4th edn. Edited by T. G. Hicks and N. Chopey. New York: McGraw-Hill Education.

Haryanto, A. 2018. Perancangan Agitator pada Proses Pemasakan Kecap dengan Pertimbangan 
Karakteristik Dinamik. Institut Teknologi Bandung.

Hubeis, M. et al. 2013. Strategi Produksi Pangan Organik Bernilai Tambah Tinggi yang Berbasis Petani.Jurnal IImu Pertanian Indonesia, 18(3), pp. 194-199. Available at: http://journal.ipb.ac.id/index.php/JIPI/article/view/8397.

Kuala, S. I., Siregar, Y. H. and Susanti, N. D. 2016. Design Control for Total Dissolved Solid (TDS) in Hydroponics System Using CCT53200E. Serpong.

Lallane, M. and Ferraris, G. 1998. Rotordynamics Prediction in Engineering. 2nd edn. John Wiley \& Sons, Inc.

Parvizi, S. et al.2016. Investigating Factors Affecting on the Efficiency of Dynamic Mixers. Mineral Processing and Extractive Metallurgy Review. Taylor \& Francis, pp. 1-27. doi: $10.1080 / 08827508.2016 .1218868$.

Paul, E. L., Atiemo-obeng, V. a and Kresta, S. M. 2004. Handbook of Industrial Mixing: Science and Practice. New Jersey: John Wiley \& Sons, Inc.

Paulo, P. V. D. L. 2011.A Time-Domain Methodology for Rotor Dynamics: Analysis and Force Identification. Universidade de Lisboa.

Rao, S. S. 2011. Mechanical Vibrations. 5th edn. New Jersey: Prentice Hall, Inc.

Rosliani, R. et al.2005. Budidaya Tanaman Sayur dengan Sistem Hidroponik. 1st edn. Bandung: Balai Penelitian Tanaman Sayuran. Available at: www.balitsa.or.id.

Suharyanto, H. 2011. Ketahanan Pangan. Jurnal Sosial Humaniora, 4(2), pp. 186-194.

Tiwari, R. 2010. Finite Element Analysis of Simple Rotor Systems. in. Available at: https://www.coursehero.com/file/9921790/rtiwari-rd-book-04/.

Trejo-Téllez, L. I. and Gómez-Merino, F. C. 2012. Nutrient Solutions for Hydroponic Systems. in Asao, F. C. G.-M. and ED1 - Toshiki (eds) Hydroponics. Rijeka: IntechOpen, p. Ch. 1. doi: $10.5772 / 37578$.

Wilson, C. E. 1997. Computer Integrated Machine Design. Edited by S. Helba. New Jersey: Prentice Hall, Inc.

Wirakartakusumah, A. 1992. Peralatan dan Unit Proses Industri Pangan. Bogor: Institut Pertanian Bogor. Available at: https://books.google.co.id/books/about/Peralatan_dan_unit_proses_industri_panga.ht ml?id=geypnQAACAAJ\&redir_esc $=y$. 